\title{
Dimitar Nikolovski
}

\section{EUROPEAN INTEGRATION AS NEW NATIONAL MYTHOLOGY: ON THE RESOLUTION OF THE MACEDONIAN NAME DISPUTE}

\begin{abstract}
The paper examines the effect that the resolution of the naming dispute between North Macedonia and Greece has on the re-definition of the Macedonian nation. It discusses the narratives of supporters and opponents to the Prespa Agreement and poses the question of whether the European integration (under which auspices the name change occurred) has indeed served as new national mythology for Macedonians.

KEYWORDS: North Macedonia, Greece, Zaev, national identity, national mythology, Western Balkans, populism, European integration.
\end{abstract}

\section{INTRODUCTION}

The SDSM- (Social Democratic Union of Macedonia) led government in the Republic of North Macedonia has been lauded by Western liberal forces as a bright example of progressive politics in the otherwise troublesome region of the Western Balkans. The government came to power in 2017 after an 11-year-long reign of the conservative VMRO-DPMNE (Internal Macedonian Revolutionary Organization - Democratic Party for Macedonian National Unity), which was characterized as "state capture" by Western critics. SDSM, along with its junior partners from the ethnic Albanian camp, formed the government after a long period of civil and partisan oppositional activism in the country, culminating with the Colorful Revolution in the summer of 201G. Though, without a doubt, challenged by the evergreen problems of systemic corruption, what earned the praise of Euro-Atlantic elites was the readiness of the new government to close the "big national questions," all in the direction of integration into NATO and the EU. This strategy rests on three, very contentious, pillars:

1. Fixing relations between the majority ethnic Macedonians and the less numerous ethnic Albanian community, mainly through a new law on languages, through which more extended linguistic rights would begiven.

2. Improving relations with the neighbor to the east - Bulgaria - with the 
purpose of gaining greater support in Euro-Atlantic integrations. 3. Solving the 27-year-old "name issue" with the southern neighbor Greece, which has definitely impeded said integration, mainly through NATO.

All three actions have produced some results. Following the signing of the agreement with Greece, the country was invited to join NATO, and is now waiting for the start of EU membership negotiations. The new law on languages entered into force and is facing practical challenges, as well as resistance from ethnic Macedonians. The Agreement for Friendship, Good Neighborly Relations and Cooperation between the Republic of Bulgaria and the Republic of Macedonia was signed on 1 August 2017 by the prime ministers of the two countries, ratified by both parliaments since. It provided for the establishment of bilateral expert commissions to discuss burning historical issues, and has produced much commotion, especially within the framework of European integration and Bulgaria's pressures to resolve the issue of naming the "Macedonian language."

All three pillars have been opposed by VMRO-DPMNE, including non-partisan civil activists, and a radical left party - Levica (the Left) — which was born out of the anti-VMRO-DPMNE protests.

This paper is dedicated to the most burning of the three issues - the resolution of the name disagreement with Greece, and the effects it is having on the citizenship definition and cleavages within the country. In particular, for the purposes of this volume, it discusses whether European integration might serve as a new national mythology for Macedonia.

\section{A MULTI-ETHNIC NATION?}

This paper is inspired by several statements of Prime Minister Zaev in which he speaks of a multi-ethnic nation. For the purposes of the dedicated volume, I use George Schöpflin's chapter titled The Functions of Myth and a Taxonomy of Myths in the influential volume Myths and Nationhood (1997), edited by Schöpflin and Geoffrey Hosking. I use the case study of the referendum on the name change in Macedonia to put the two into communication.

First, the controversial statements by Prime Minister Zaev. In 2019, Zaev received the Isa-Beg Ishaković International Award in Sarajevo in recognition of his work as he "significantly improved relations in the Western Balkans region, and demonstrated strong political leadership in the context of a more decisive region cooperation with the European Union and NATO" [Sarajevo Times, 2019]. During his receiving speech, he stated, "I and my multi-ethnic people [narod] are truly lucky" [ibid]. He continued along the same lines a few days later, in a greeting 
address to Milo Đjukanović, his Montenegrin colleague from the sister party Democratic Party of Socialists: Zaev passed on the "warm greetings from the multi-ethnic Macedonian people" [Mirchevski, 2019]. These statements, quite expectedly, were severely criticized within the country. When asked to make a statement during a press conference on which people [narod] he referred to, he elaborated:

The Macedonian people in the Republic of North Macedonia is the people of the Republic of North Macedonia. And it is multi-ethnic. It is composed of Macedonians, Albanians, Turks, Vlachs, Roma, Bosniaks, Serbs and all the others who live in it. So the phrase the multi-ethnic people of Macedonia, or of the Republic of North Macedonia is the term we are now using. I use it on purpose because I believe that we are a multi-ethnic country with multi-ethnic people, but we are still all Macedonian people. Who belongs to the Republic of North Macedonia [Sarajevo Times 2019].

Returning to the issue of mythology, what I would like to explore in this paper is whether this multi-ethnic nation is truly being formed, with the Euro-Atlantic integration as a central founding myth. To understand this more clearly, I use Schöpflin's understanding of myth, as it is "one of the ways in which collectivities - [...] nations - establish and determine the foundations of their own being, their own systems of morality and values" [Schöpflin, 1997: 19] and would like to see whether for the Macedonian nation, the compromise with Greece, especially done under the auspices of European integration, establishes a new myth. Schöpflin continues with a statement that, in this day and age, might be too monolithic for the establishing of new mythologies; he says that "myth is a set of beliefs, usually put forth as a narrative, held by a community about itself" [ibid.]. I doubt that the whole community will hold this myth to be true, even in the short term. However, what is important here is the tendency for the establishment of new mythologies. Like any mythologies, national myths need not be validated by historical truth, but rather perceptions are at the forefront. Schöpflin notes, however, that myths are not about falsehoods and perceptions, since communities might be aware they are not rooted within historical facts. Content, therefore, is of vital importance. To finalize with Schöpflin's words in this section: "Myth is, then, a key element in the creation of closures and the constitution of collectivities. At the heart of this argument is the proposition that myth is vital in the establishment of coherence, in the making of thought-worlds that appear clear and logical, in the maintenance of discourses and generally in making cosmos out of chaos." [ibid: 20]

European integration in the Western Balkans has taken some of the qualities of mythology, and the desirability of membership has not been disputed by the political mainstream throughout the problematic transitions. As it will be seen, the resolution of the naming dispute invariably influences the identity of the 
people inhabiting what is now called North Macedonia. However, this bitter pill to swallow has been justified precisely through the promise of a better life under NATO membership and, more specifically, the European Union. Thus, the central question of this paper is this: is Macedonia's Euro-Atlantic integration a key element in new national mythology?

The question will be explored through the contention arising from the process of changing the name, and the referendum in particular.

\section{THE CONTEXT OF THE AGREEMENT}

The Prespa Agreement, signed on 12 June 2018, ended a 27-year-old dispute between Greece and Macedonia. In short, after the declaration of independence from the Yugoslav Federation, the newly established Republic of Macedonia faced difficulties of recognition, primarily from its southern neighbour, Greece. The Greek administration of the time purported that the very usage of the name "Macedonia" meant territorial pretensions, considering that it coincided with the name of its northern region of the same name, even though the name of the country had been Federal or the Socialist Republic as part of Yugoslavia since the end of World War II. Seeing no way out, the Macedonian side accepted being taken into the United Nations under the provisional name The Former Yugoslav Republic of Macedonia (FYROM), provided that the two countries would hold talks on a permanent solution to the naming dispute. This very issue has been a potent breeding ground for heightened nationalism on both sides of the border in the years to come.

Despite the obvious problem, the two countries cooperated, especially in the economic field, very successfully, while the UN, under special negotiator Matthew Nimetz, sought to help the parties overcome the differences on the name. Following a Greek-initiated veto on a NATO membership for Macedonia in 2008, the VMRO-DPMNE government (200G-2017) used a well-known strategy of increasing popular support -increasing nationalism. The core of the issue was that the use of the word Macedonia in the Republic of Macedonia meant that the country and its people laid claim on the ancient kingdom of Macedon, along with its most famous ruler Alexander the Great. Even though such a sentiment was present, practically the identity of Macedonians had always been connected to Slavic culture. However, the VMRO-DPMNE government engaged in a redefinition of national identity. Though predominantly Slavic, it moved ancient Macedonian identity to the forefront, primarily through architecture, i.e. the controversial Skopje 2014 project, when a giant statue of Alexander was built on the square, along with the entire royal family and buildings in a neoclassical/baroque style. 
After the change of government, and with increased support and pressures from both EU and US representatives, as well as by considering the specificities of the Greek government of the time, the agreement was finally reached. In short, the new name of the country would be the Republic of North Macedonia, both internationally and within the country. The language remains Macedonian, but with an emphasis that it belongs to the family of Slavic languages, while the citizenship is designated as Macedonian/of the Republic of North Macedonia.

Considering the national consensus among all mainstream parties that once an agreement with Greece is reached, the solution would have to go to a referendum; this option was granted by the agreement itself. The date for the referendum was set for 30 September 2018, setting the scene for a tense summer in political terms.

The question for the referendum read: "Are you in favour of NATO and EU membership through accepting the Agreement with Greece?" Highly contested, the question was set this way to suggest that the name change is for no other

reason than to lift the Greek veto preventing accession to international organizations due to the existing problem.

\section{THE EXISTING CLEAVAGES}

In this paper, I claim that we are witnessing in Macedonia two opposing mythologies that continuously divide society into two monolithic camps. Whereas the right-wing mythology of VMRO-DPMNE and affiliated organizations seek to represent the "people" in an ethno-nationalist sense, the left-wing mythology of SDSM and its affiliates claim to represent the "citizens" in a multi-ethnic state. Both camps claim to represent Macedonian citizens on a large scale. Both camps have supporting media that exacerbate this understanding of their constituencies, however, similarly, they may act with only minor differences in wording.

Furthermore, I claim that two parallel civil societies exist today - one, already established and modelled based on Western imaginations of civil societies in transition, and another, in its birth, as an antithesis to the previous one (could be labelled "uncivil"). In the attempt of establishing a populist chain of equivalences, the two civil societies have a different definition of their constituencies. The leftwing civil society represents the "citizens" - a multi-ethnic, vigilant, aware, and pro-Western citizenry, with an orientation towards the substantive understanding of democracy. On the other hand, the right-wing civil society represents the "people" - largely ethnically Macedonian; proud, resistant to the "corrupt West," and with a clear preference to the procedural, majoritarian understanding of democracy.

Whatever had been started during the rule of VMRO-DPMNE in 200G-2017, the referendum on the name change has strengthened and clarified. 


\section{THE EUROPEAN (NORTH) MACEDONIANS}

The question itself implied the direction of the Yes campaign. The main slogan used by this camp was "For a European Macedonia." On campaign rallies, internet campaigns and TV appearances (headed by Prime Minister Zoran Zaev) Yes campaigners primarily spoke of the benefits of membership.

NATO membership gained some attention, expectedly in the direction of better security, as being a part of a larger family and being in a military alliance with neighbours: Greece, Bulgaria, and Albania. Security is particularly important because of the memories of the 2001 conflict between state armed forces and ethnic Albanian insurgents. The ever potent perception of "threat" from Albanian nationalism and separatism was used both informally and formally, posing the imperative that these "appetites" would be finally settled once the country entered NATO.

The EU, on the other hand, was dominating the campaign as a powerful strategic goal of the country and its citizens. It was approached in both a civilizational and practical way. The civilizational aspect was that Macedonia had always been a part of Europe, both geographically and culturally, thus we would need to remove any obstacles impeding us from it. This notion was always juxtaposed to the East, especially Russia. Thus, the dichotomy emerged between the Europe of democracy, human rights and high culture, and the East, like Russia and Turkey, i.e. autocracies and models of the past.

In practical issues, the story was told through both truthful and augmented representations of what the EU might mean for Macedonian citizens. Much like an electoral campaign, it was presented that the Yes vote would bring more employment, better-paid jobs, the opening of new markets, mobility for the youth, even free healthcare in Europe. Most importantly, European integration meant an end to the "voting by feet," i.e. would stop people from migrating out of the country for economic reasons. This aspect, however, was coupled with the identity question as well.

For ethnic Macedonians, the primary and easiest exit ticket from the country was getting a Bulgarian passport since Bulgaria is an EU member state. The question of Bulgaria is the other contentious issue for Macedonian identity, after the Greek one. Besides Greece and the naming issue, Macedonia has conflicting national mythology with Bulgaria at its core. Bulgarian historiography states that the Macedonian nation, language, culture and identity do not exist as separate entities, but are essentially Bulgarian. Thus, for a Macedonian national to receive Bulgarian citizenship, one should sign a notarized statement that they are Bulgarian, along with all their ancestors. Thus, whenever a Yes campaigner would say that EU membership would stop people from wanting to move out, it also 
meant stopping Macedonians from becoming Bulgarian and keeping the Macedonian identity. The name change should be a sweet pill to swallow then.

The composition of the Yes camp was the following:

- SDSM supporters, since it was signed by this party in power. Overall, these voters tend to be less nationalistic, more multi-ethnic and more enthusiastically pro-European.

- Supporters of ethnic Albanian parties, since all of them (both opposition and incumbent) publicly supported the agreement. Ethnic Albanians are less emotionally involved in the name issue and have continuously claimed that NATO and EU were the most important strategic goals for them, even at the expense of conflict, especially after Albania entered NATO.

- Less numerous ethnic groups (Bosniaks, Roma, Aromanians, etc.), for similar reasons like Albanians.

- A significant part of Colorful Revolution participants, since their definition of citizenship, coincided with the EU idea.

\section{G. THE MACEDONIANS OF "BOYCOTT”}

Practically, an "Against" campaign did not materialize. Rather, from the onset, boycott was seen as the only option for the opponents of the agreement. The explanation why boycott was the preferred option holds several layers:

- By law, a referendum is only successful if a 50\% quorum is reached. Having in mind the enormous success of SDSM at the local elections of the previous year, coupled with the support by Albanians and other ethnic communities, opponents were not certain that there would be more votes against than for. Electoral math supported this claim. Roughly 1.8 million voters are on the voting list, according to the State Electoral Commission. The list has been contested for years but has not been cleaned yet. It does not help either that the country has not held a census since 2002 . Usually, there are no more than 1.2 million voters at elections due to migration and political disinterest. Thus, putting the apathetic and those unable to vote (being abroad, etc.) together with those opposing the agreement would prove successful in the creation of a picture that more people oppose the agreement.

- The second reason why boycott was simply rhetoric was that they did not want to decide. In the words of one of my informants: "Our ancestors fought and died and voted for this country in the present form. This name is given to us as a legacy. I do not have the right to vote in any way on this. This question cannot be." For boycotters, it was considered a bad solution that should not be legitimized. 
- The third reason was simply institutional distrust. According to boycotters, if you vote, you have no guarantees that it would not simply be counted as a 'yes.' If you boycott, it is more difficult for them to fake it!

- Finally, the fourth reason was the name itself. For boycotters, the name was manipulative and contained a whole matrix of possible answers, one that should not be answered.

The symbolic production of the boycott camp indicates the birth of the Macedonian alt-right: Nationalism coupled with institutional distrust and antiestablishment politics. The boycott campaign never said it would stop there, but rather that it would continue to fight against the current government and take back the country. In addition, Steve Bannon and Pepe the Frog were used as symbols. Thus, the move to change the name was presented as part of the globalist conspiracy headed by the deep state, epitomized through George Soros and his puppets in the EU. Hashtags such as \#deepstate, \#bannon, \#Qanon, were used to give it international context, and to show the Macedonian struggle as one worthy of solidarity with other peoples fighting globalist powers. The moral argument went that the name change was genocide against Macedonians. Considering that the EU supported it, it also fits within the story of building refugee camps in the country. At the final rally, protesters wore David's stars on their sleeves, to show the parallel between the Macedonian name genocide and the Holocaust.

Most interestingly, the boycott campaign employed populist tactics more successfully than the 'yes camp'. Boycott emerged as the empty signifier arising from an equivalent chain of a plethora of sedentary and current grievances. According to its participants, Boycott was the culmination of national deficiencies, such as criminal transition and offended national pride with relations to Greece, Bulgaria, and the Albanians. On the other hand, Boycott was also a resistance against the global conspiracy, so Macedonia fought for conserving Christian Europe from the globalists and Muslim migrants. In addition, if you had boycotted, it would mean that you also reacted against current scandals. Such was the dubious distribution of innovation grants to companies close to government officials, or the fact that the daughter of the foreign affairs minister has won a governmental scholarship to study in the Netherlands. Finally, it also meant that you were angry with the mayor of Skopje for not having fought against the scourge of mosquitoes during the summer well enough.

The composition of Boycott was primarily ethnic Macedonian, the majority belonging to various right-wing organizations:

- The most vocal was a coalition of smaller, newly formed political parties and formal and informal civil society groups, with the United Macedonia being the most notable of all, which was a direct copy of Putin's United 
Russia with blunt pro-Russian sentiments. They were joined by the World Macedonian Congress, an umbrella organization of diaspora groups.

Furthermore, they were supported by newer right-wing groups such as the Hardcores (Tvrdokorni) and the Christian Brotherhood.

- The main opposition party, VMRO-DPMNE, played a tricky role. Being vocally against, they never called for a boycott, but insisted that everyone should act "in accordance to their conscience." In the field, however, it was obvious to the members that an unofficial direction was still to boycott.

- The most significant "transfer" from the Colorful Revolution to Boycott was Levica - the Left - a radical left-wing party, born out of anti-VMRODPMNE protests. According to them, the agreement endangered the fight for self-determination, it was imperialistic, and anyways, the country should not join NATO. This coalition produced some unexpected results, such as Hardcores, a proto-fascist organization, supporting and promoting events in a leftist social centre with anarchist bands, just because they were anti-NATO.

\section{THE REFERENDUM OUTCOME}

On 30 September 2018, only 3G.9 percent of voters participated in the referendum, $91.4 \%$ of whom were in favour of the agreement. It meant that out of the 1.8 million official voters only about G00,000 supported the name change [BBC News 2018]. Both sides declared victory. Since it was merely a consultative referendum, and since the voter list was not valid, the Yes camp, i.e. the government, would proclaim that the numbers showed a clear indication of the general will. Thus, they would go ahead with constitutional changes.

Boycott, on the other hand, also celebrated. Considering only $37 \%$ voted, they believed that 1.2 million people opposed the agreement, thus the government has lost its mandate to continue pursuing its goal. After the law on languages and the agreement with Bulgaria, this was the first time one could see the Macedonian right-wing celebrate on the streets. They pledged to prevent further enactment of the agreement, and are currently pushing for resignation and trial of the government for high treason. Boycott has turned into Resign and Arrest.

As previously mentioned, this referendum solidified cleavages in the Macedonian political spectrum, with one significant change: that of the Left. It also gives the rise to the Macedonian alt-right, as a prominent part of the wider right-wing movements.

\section{THE NEW MYTHOLOGY DISCUSSED: A CONCLUSION}

When discussing the functions of myths, Schöpflin sees it as an instrument of self-definition, membership and rules, world view, and boundaries of the 
community [Schöpflin, 1997] According to this understanding, the new mythology in North Macedonia would be that of a multi-ethnic European nation, one that would espouse in its citizens the values of the progressive politics of the EU, and with a membership which would distinguish it from other, non-European Union nations. In this sense, it is visionary mythology that expects an "easing" of nationalist narratives at the expense of European ones, even amongst its neighbours. In opposition to this, protesters against the new name choose to keep the boundaries as they are, with a clearly defined Macedonian nation within the state.

Myth can be an instrument of identity transfer [ibid.], as a new identity can be superimposed on an older one. Following this, it can be suitable for ethnically different groups to be brought closer or even assimilate together. In the case of North Macedonia, the new mythology would build an identity past the ethnic and religious diversity that exists at the moment. This would be a European identity, holding the mythology of the process of European integration, in particular by accepting the name change, as well as the new law on languages. This would, consequently, alleviate the inter-ethnic tensions threatening to destabilize the country. This European identity is exactly what the other side is fearful of: the loss of any domination for ethnic Macedonians and the superimposed increase of domination by other communities, particularly Muslim Albanians, under the guise of European, multi-ethnic nationhood.

Another, very interesting observation that Schöpflin makes about mythologies is that "of offering explanations for the fate of a community, for accounting for failure, for the negative outcomes of particular strategies" [ibid: 25] Especially regarding failures, this aspect of mythologies can lead to conspiracy theories. The fact that the Macedonian nation has identitarian issues with several of its neighbours, has been strengthening conspiracy theories, especially among the opponents to the agreement. According to them, the name Macedonia is too glorious, and the Macedonians, as Alexander the Great's descendants, have to fight to preserve it. Since all neighbours are against the nation, it means that there has to be some sort of global conspiracy to crush the nation. The name issue with Greece has, not without some accuracy, been used as a constant reason why the country could not progress economically and politically. Its resolution, however, can be used by the other side, as a founding event in the birth of the new European nation, not only attributing all future improvements in life to it, but also with a clear delineation where the fault might be if things are tough.

To finalize, Schöpflin writes that the myth needs to have the strength to mobilize, it needs to resonate. It is open to question whether the new mythology of a European multi-ethnic Macedonian nation, with the founding event of the name agreement with Greece, would survive, or will continue to be alien to most of the community. The numbers showed that, in a nation of roughly two million 
inhabitants, more than G00,000 supported it. Even though boycotters claim that 1.2 million (out of the complete voter lists), are against it and wish to keep things as they are. The conflict between these two mythologies will continue to shape Macedonian politics in the coming years.

\section{BIBLIOGRAPHY}

"Macedonia referendum: Name change vote fails to reach threshold". BBC News (website), 2018. https://www.bbc.com/news/world-europe-45G99749 Mirchevski, Ivan. „Заев во обид да измисли нов мултиетнички македонски народ" [Zaev attempting to invent a new multiethnic Macedonian people]. Alfa (TV website), Nov. 30, 2019, https://alfa.mk/zaev-vo-obid-da-izmisli-novmultietnichki-makedonski-narod/

„Zaev insists that the Macedonian people is a multi-ethnic mix”, Republika (website). Dec. 5 2019, https://english.republika.mk/news/macedonia/zaev-insists-that-themacedonian-people-is-a-multi-ethnic-mix/

Zoran Zaev received the Isa-Beg Ishakovic International Award". Sarajevo Times (website), Nov. 30, 2019, https://www.sarajevotimes.com/zoran-zaev-won-the-isabeg-ishakovic-international-award/

Schöpflin, George, 1997. „The Functions of Myth and a Taxonomy of Myths” In Myths and Nationhood, ed. Geoffrey Hosking and George Schöpflin, 19-35. New York: Routledge

\section{DISCLOSURE STATEMENT}

This research has been completed while the author worked at the Institute for Advanced Studies in Koszeg, Hungary. A previous version has been published as part of a book dedicated to George Schopflin for his 80th birthday titled: Navigating Through Troubled Waters, eds. Ferenc Miszlivetz and Attila Pok. 
